\title{
Assessing social capacity and vulnerability of private households to natural hazards - integrating psychological and governance factors
}

\author{
J. Werg ${ }^{1}$, T. Grothmann ${ }^{2}$, and P. Schmidt ${ }^{1}$ \\ ${ }^{1}$ Potsdam Institute for Climate Impact Research, P.O. Box 6012 03, 14412 Potsdam, Germany \\ ${ }^{2}$ University of Oldenburg, 26111 Oldenburg, Germany
}

Correspondence to: J. Werg (jana.werg@ @ik-potsdam.de)

Received: 30 November 2012 - Published in Nat. Hazards Earth Syst. Sci. Discuss.: Revised: 29 March 2013 - Accepted: 10 April 2013 - Published: 21 June 2013

\begin{abstract}
People are unequally affected by extreme weather events in terms of mortality, morbidity and financial losses; this is the case not only for developing, but also for industrialized countries. Previous research has established indicators for identifying who is particularly vulnerable and why, focusing on socio-demographic factors such as income, age, gender, health and minority status. However, these factors can only partly explain the large disparities in the extent to which people are affected by natural hazards. Moreover, these factors are usually not alterable in the short to medium term, which limits their usefulness for strategies of reducing social vulnerability and building social capacity. Based on a literature review and an expert survey, we propose an approach for refining assessments of social vulnerability and building social capacity by integrating psychological and governance factors.
\end{abstract}

\section{Introduction}

The impacts of events like the European heat wave in 2003, the landfall of Hurricane Katrina near New Orleans in 2005, and the flooding of large parts of Queensland (Australia) in 2010/2011 demonstrated that industrialized countries are not immune to high losses from extreme weather events. Also, like in developing countries, large disparities exist in social vulnerability to natural hazards; people are unequally affected in terms of adverse health effects, loss of life and property (e.g. Curtis et al., 2007). The frequency of weatherrelated extremes such as heavy precipitation events and heat waves will very likely increase due to climate change (Meehl et al., 2007), so that in all likelihood more people will be affected in the future. In order to understand potential consequences of natural hazards for humans, to better understand who is particularly affected and why, and to reduce negative impacts of natural hazards, the concept of social vulnerability was developed. There are a vast number of definitions of social vulnerability (cf. Tapsell et al., 2010); following a definition of vulnerability common in natural hazards and disaster research, we understand social vulnerability as "the characteristics of a person or group and their situation that influence their capacity to anticipate, cope with, resist, and recover from the impact of a natural hazard ${ }^{1}$ " (Wisner et al., 2004, p. 11). Many attempts have been made to measure social vulnerability (for comprehensive overviews see Adger et al., 2004; Adger, 2006; Tapsell et al., 2010; also see Hufschmidt, 2011); so far, social vulnerability assessments have relied mainly upon socio-demographic indicators such as age, gender, and household income (see Sect. 2.1). Sociodemographic indicators refer to inherent aspects of vulnerability that are rather static, at least in the short to medium term: people cannot become younger or change their ethnicity, and increasing poor people's income is an essential yet long-term challenge in vulnerability reduction. Thus, assessments limited to socio-demographic indicators are also limited regarding their usefulness for vulnerability reduction (e.g. through supporting decisions on monetary flows and particular consideration of vulnerable population groups in emergency plans).

Going beyond socio-demographic indicators for the assessments of social vulnerability can substantially contribute

\footnotetext{
${ }^{1}$ We understand a natural hazard as "purely physically defined" (Adger et al., 2004, p. 28), the impact of a hazard reflected in lives lost, people affected and economic losses (cf. ibid).
} 
to a better understanding of exactly which capacities people lack that enable them to deal with natural hazards. Such knowledge is the prerequisite for the effective building of social capacity and thereby reducing people's vulnerability. Psychological factors such as the perception of being at risk ${ }^{2}$ from a hazard, the knowledge of self-protection and the motivation to actually carry out such measures are important elements of social capacity. At the same time, governance factors creating an environment that protects those that are vulnerable from the adverse impacts of natural hazards and increases people's ability to protect themselves, are essential components of social capacity building and vulnerability reduction. Moreover, psychological and governance factors are changeable - meaning they can potentially be altered within the short to medium term, and the power to do so lies at least partially with local policy makers and private persons. The purpose of our research was to identify a set of indicators that would allow a refinement of common assessments of social vulnerability and offers possible starting points for vulnerability reduction and social capacity building at the local level. Using the term local level, we refer to the household and community levels, being the most crucial for loss prevention behaviour and measures (cf. Hufschmidt, 2011).

Following the process of our research, the paper is organized as follows: first we will give an overview of the results of our literature review of indicators of social vulnerability and social capacity building. Second, we will describe the expert survey conducted to assess the perceived relevance of the indicators reviewed and outline the survey's results. The last part of the paper will be dedicated to the conclusions; a possible nested approach to detecting and reducing vulnerability and building social capacity, and future research steps will be discussed.

\section{Literature review}

Three questions were guiding our literature research: on the individual level, what are the factors that make people vulnerable to natural hazards? Which factors increase social capacity or the likelihood of people taking action to reduce their own vulnerability? On the community level, which factors influence the vulnerability of a community and its residents? In dealing with all of these questions, we were interested in indicators ${ }^{3}$ representing those factors. Possible answers to

\footnotetext{
${ }^{2}$ We understand "risk" as the likelihood of a natural hazard combined with the likely impact of the hazard on peoples' lives, family and property (cf. Adger et al., 2004, p. 33). With "risk perception", we refer to people's perception of this likelihood and the perceived severity of the consequences.

3 We use the term "indicator" referring to an indicator's name; measurable units need to be assigned to the indicators for their use in surveys. In the research work presented, the operationalization of the indicators varied - while yet referring to the same phenomena. Strictly speaking, many of the traditional indicators (e.g. "age") are
}

those questions can be found in research on social vulnerability to natural hazards, social vulnerability to climate change, social vulnerability reduction, loss prevention and social capacity building. Our focus is on studies of weather-related extremes (heat waves, floods (fluvial, pluvial, tidal), storms). With a very likely increase in such extremes due to climate change (Meehl et al., 2007), the question of how people deal with these natural hazards is also increasingly relevant. In presenting the results of the literature review, we distinguish between (a) different natural hazards (categories heat, flood, storm) and (b) different categories of indicators, i.e., traditional indicators (those commonly used in vulnerability assessments), psychological and governance indicators. For the traditional and the psychological indicators, we have only included surveys or case studies that analyse the correlation between certain factors or indicators on the one hand and impacts of natural hazards (mortality, morbidity, financial losses) or loss prevention behaviour on the other hand. By correlation we refer to an observed quantitative relation indicated by statistical correlation, factor analysis, or percentage (e.g. $75 \%$ of the fatalities were elderly). Some studies solely rely upon secondary statistical data, assuming a strong positive correlation between certain indicators and vulnerability without analysing actual correlations of those indicators to the outcomes (e.g. fatalities) in a certain event (for discussions of different approaches cf. Hinkel, 2011; Kuhlicke et al., 2011a; Tapsell, 2005). Such studies were not included for the traditional and psychological indicators. However, for the governance indicators, such a strict limitation would have led to very few results. Therefore, the aforementioned types of studies were also included for the research on the governance factors, as were studies based on a "theoretical understanding of relationships" (Tapsell et al., 2010, p. 27).

\subsection{Traditional indicators - focus on assessing inherent vulnerability}

Previous research on social vulnerability has focused on indicators such as age, gender, and household income (e.g. Brooks et al., 2005; Cutter et al., 2003; Demetriades and Esplen, 2010; Gladwin and Peacock, 1997; Jonkman et al., 2009; Masozera et al., 2007; Mearns and Norton, 2010; Morrow, 1999; Reid et al., 2009; Tapsell et al., 2002). These traditional indicators are used individually or as part of a vulnerability index (e.g. Fekete, 2009; Cutter et al., 2003; for an overview on four major indices see Birkmann, 2007). Vulnerability assessments based on traditional indicators follow well-established procedures, with the indicators referring to available data such as census data. Common outputs of such vulnerability assessments are vulnerability maps, highlighting vulnerable areas of different scales (e.g. country, county,

not actual indicators in the sense that "indicators are used to assess the change over time of processes or phenomena that are difficult to measure" (Tapsell et al., 2005, citing from Cobb and Rixford, 1998). 
city) (e.g. Cutter and Finch, 2008). Other studies empirically test assumed linkages between indicators of socio-economic characteristics and demographic factors on the one hand and vulnerability on the other (e.g. Brooks et al., 2005; Cutter et al., 2003; Fekete, 2009). Table 1 lists those traditional indicators, for which we found surveys or case studies testing the correlation between those indicators and financial losses, mortality, morbidity and loss prevention behaviour.

\subsection{Psychological indicators - focus on correlates of vulnerability reduction behaviour and social capacity building}

In the context of our work, psychological indicators refer to cognition, emotions and experience relevant to human action, more precisely, vulnerability reduction behaviour (cf. Grothmann, 2005). The starting point for our research on psychological indicators were Grothmann's reflections (Grothmann, 2005) on the Protection Motivation Theory (Rogers and Prentice-Dunn, 1997) and his model of private precautionary damage prevention (Grothmann and Reusswig, 2006). These models take into account psychological factors for analysing why "some people take precautionary action while others do not" (ibid, p. 101). We included those psychological indicators for which we found surveys or case studies testing the correlation of the indicators and individual vulnerability reduction or loss prevention behaviour. Such behaviour can substantially reduce people's vulnerability (World Bank and United Nations, 2010). For example, there are several low-cost measures in responding to a heat warning (e.g. drink more fluids, stay indoors). Yet, many people, despite being aware of such a warning, do not respond accordingly (Sheridan, 2007). Surprisingly, there is very little research on exactly which psychological factors play a role with regard to how people act upon heat warnings (cf. Kalkstein and Sheridan, 2007). Also, the potential of private loss prevention measures is impressive. For example, financial losses caused by flooding can be reduced by up to $80 \%$ through private measures such as water barriers installed at the house (Egli, 2002, p. 43; also see Botzen et al., 2009; Kreibich et al., 2005, 2012; Kreibich and Thieken, 2009). For certain private damage prevention measures, psychological factors such as risk perception have been shown to explain more variance than traditional socio-economic factors such as household income (Grothmann and Patt, 2005; also see Howe, 2011). Krömker and Mosler (2002) describe several psychological factors or rather processes that are crucial regarding the realisation of private loss prevention measures. They also stress that "those factors must be properly addressed if people are to be persuaded to generate protection capacity" (ibid., p. 109). Consequently, to be useful for vulnerability reduction, assessments of vulnerability should also examine "individual and community social environments" (Yardley et al., 2011, p. 671; also see Mustafa et al., 2011).
For the results of the literature review on psychological indicators, please refer to Table 2 .

\subsection{Governance factors - starting points for reducing vulnerability at community level}

The relevance of governance factors in reducing social vulnerability has been emphasized in a broad range of research work (cf. Pearce, 2003, 2005; Tan et al., 2007; Tan, 2008; White and Howe, 2002). However, although the term governance is extensively used, it is still an ambiguous concept (cf. Kaufmann and Kraay, 2008). Within this text, our understanding of governance refers to a notion of "good governance" regarding vulnerability reduction, i.e. the existence of public capacities and local institutions designed to support vulnerability reduction measures. Because of our focus on the community and household levels, we included only those governance factors that local decision makers have a direct influence on. For example, emergency plans for a community that are easy to understand, accessible and widely known can help community members protect themselves against natural hazards. Regarding floods, the importance of governance aspects such as "an active involvement of interested parties in the setting up of flood risk management plans" is reflected in their inclusion in the EU Flood Risk Management Directive 2007/60/EC (Fleischhauer et al., 2012, p. 2785). It was shown that participatory decision-making can reduce vulnerability (e.g. Pearce, 2003, 2005). Participation in dealing with risks from natural hazards can lead to a greater familiarity with the risk and can thereby increase the likelihood of the risk to be dealt with (cf. Wachinger and Renn, 2010). Governance indicators have been included in assessments of vulnerability within a set of vulnerability indicators, without being directly classified as governance indicators (cf. Carreño et al., 2007; Cutter et al., 2010; Hahn et al., 2003; Tapsell et al., 2002). There are relatively few studies on governance factors yielding empirical evidence of the relevance of those factors. Therefore, Table 3 also lists studies emphasizing the importance of certain governance factors at community level based on "a theoretical understanding of relationships" (see above, Tapsell et al., 2010, p. 27) or expert opinion, i.e. qualitative rather than quantitative arguments.

\section{Expert sample and survey}

The indicators listed in Tables 1-3 were included in an expert survey. The purpose of the expert survey was an assessment of the relevance of these indicators for identifying and targeting vulnerable population groups in industrialized countries. The survey was carried out online between 15 October and 5 November 2010. The survey language was English. Thirtyeight (38) experts were invited to participate, with ten experts actually participating (for a discussion of the response rate see Sect. 5). The experts were selected as follows: academic 


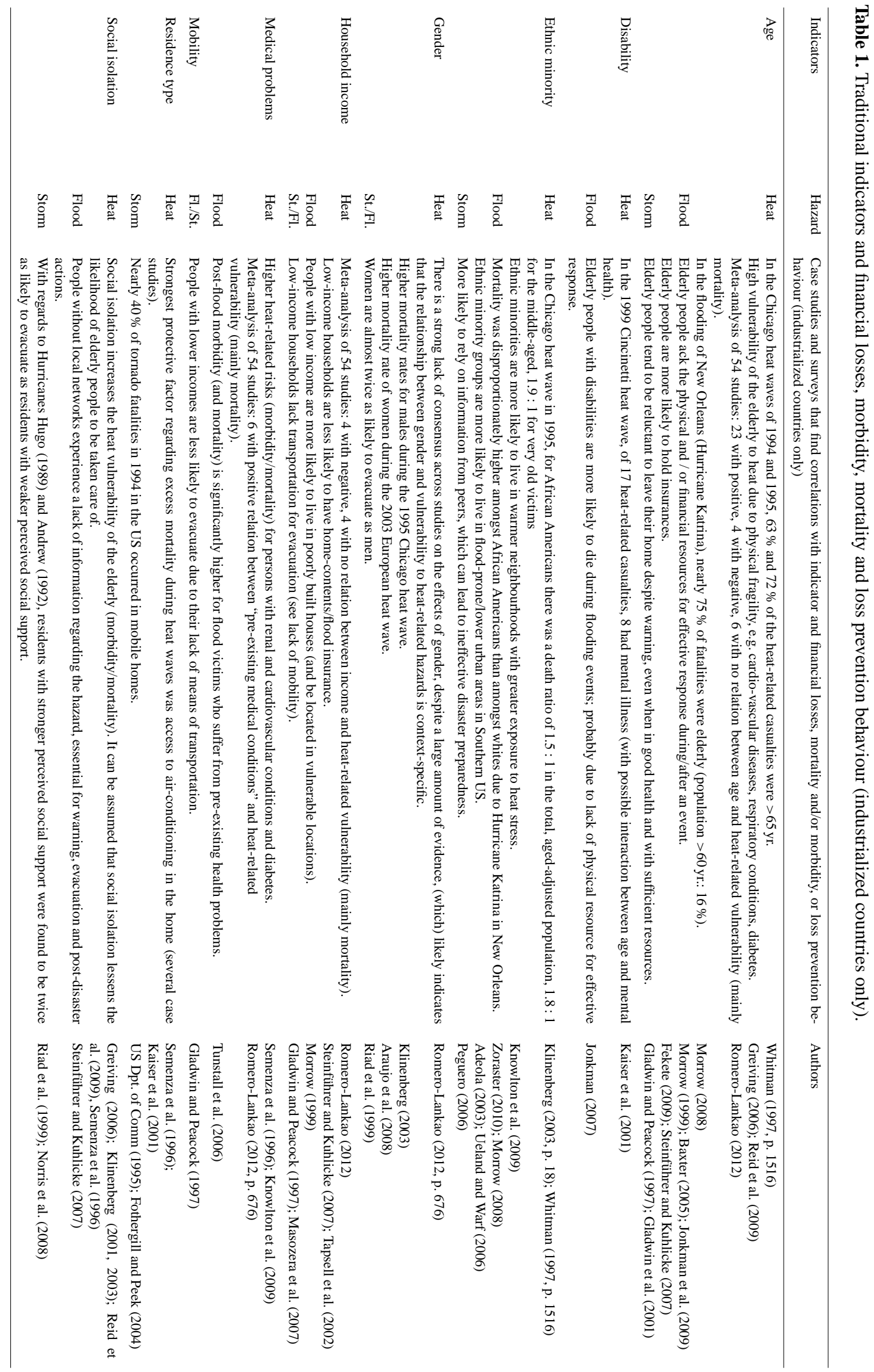




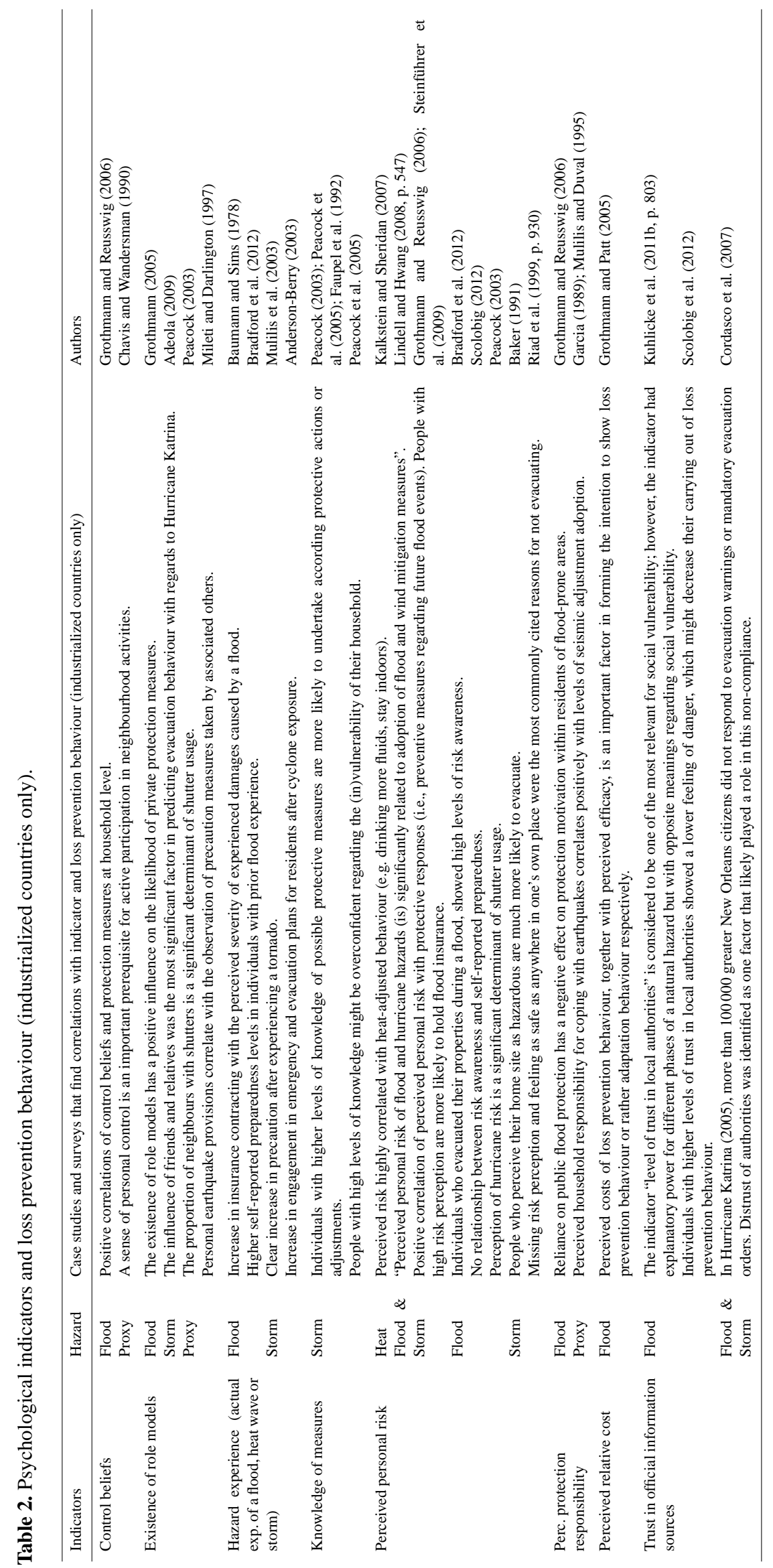




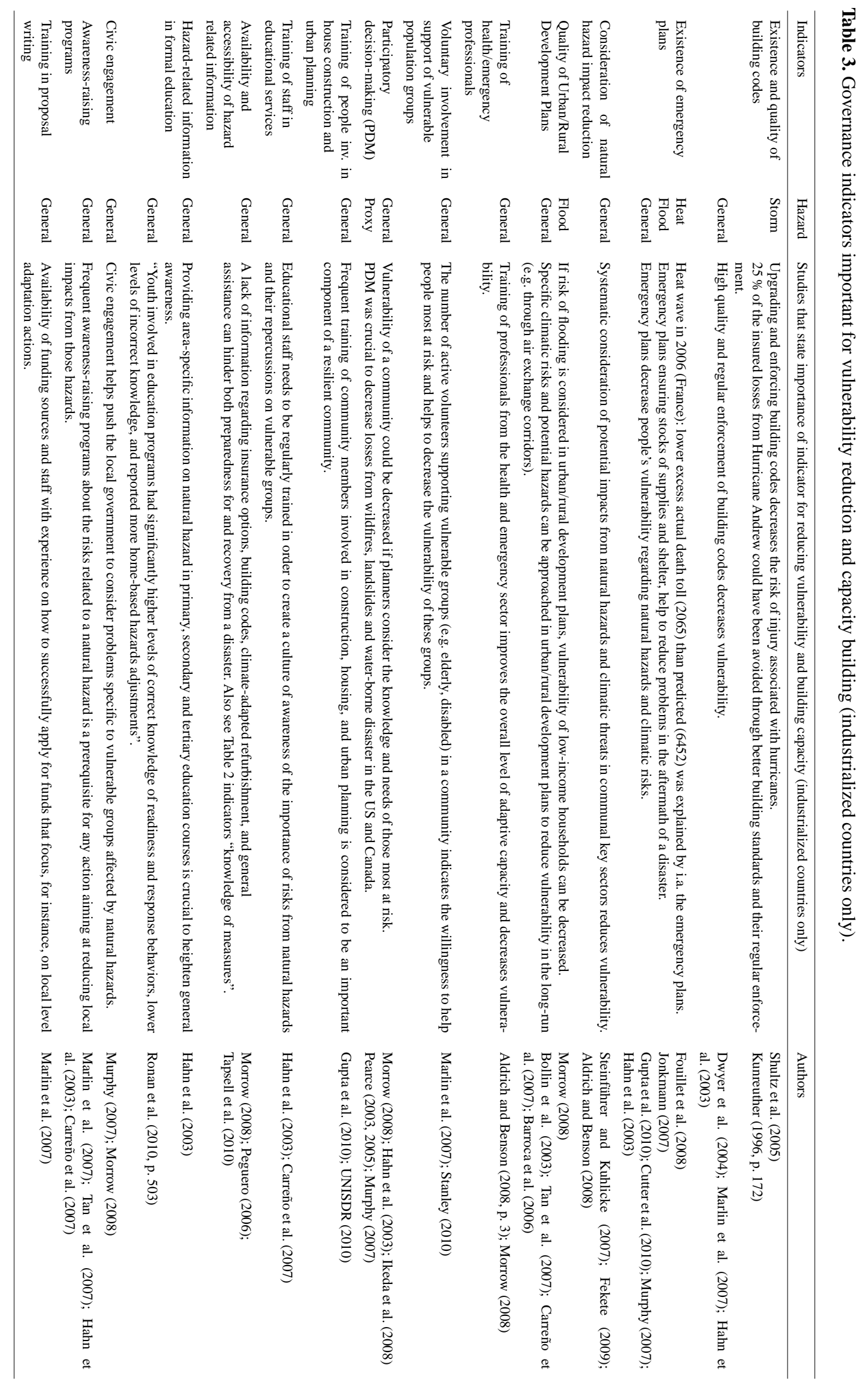




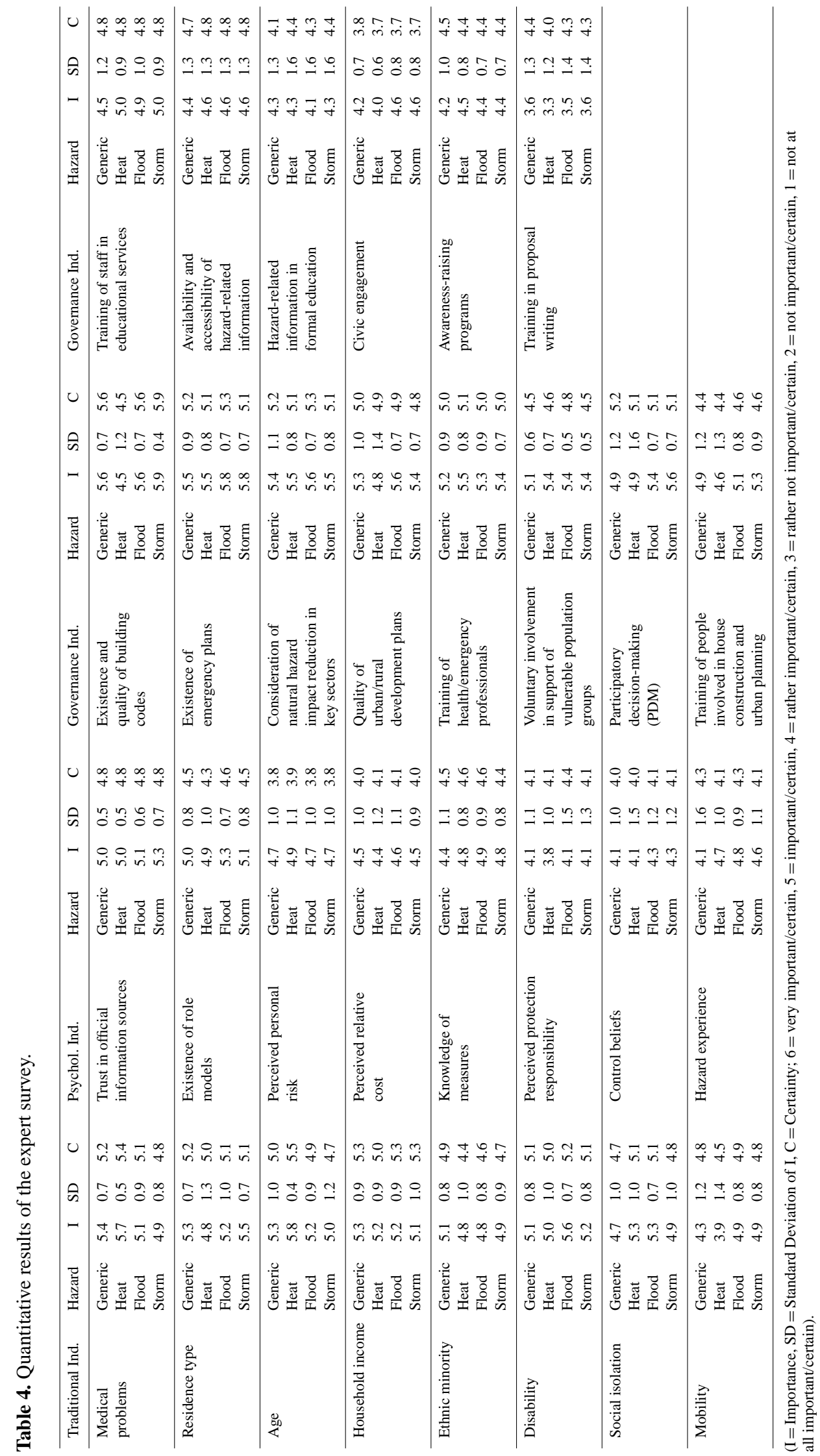


researchers with more than one scientific publication in the fields of social vulnerability to natural hazards, social vulnerability to climate change, social vulnerability reduction, loss prevention and social capacity building were considered as potential experts for the survey, representing the research fields we included in our literature review. This led to a selection of 50 experts. Within the team, we then discussed the suitability of each of those 50 experts based on their work included in our literature review, their other scientific publications and their research activities. This led to the targeted sample of 38 ( 20 female, 18 male) experts being invited to participate in the survey via email. Of the ten experts participating ( 5 female, 5 male), all are affiliated with universities or research institutions; they all hold a Ph.D.; seven of the ten experts are professors or associate professors (one of whom is a professor emeritus) in the USA (4), the UK (3), Germany (2), and Canada (1). The experts' research interests as stated on their professional or personal websites are (frequency of mention in brackets): (social) vulnerability (assessment) (5), climate change adaptation (5), climate change impacts (3), risk assessment (3), issues of global environmental change (3), sustainability (3), resilience (3) and gender (2), natural hazards (2), environmental and risk governance (2), disaster risk management and reduction (2).

In the survey, we distinguished between household and community level indicators. The household level indicators include the traditional and psychological indicators. They are directly linked with the situation of a particular household and are therefore relevant for the identification of vulnerability down to the household level. The community level indicators refer to the governance indicators that are relevant at community level. The governance indicators do not allow distinguishing vulnerabilities at household level; however, they still directly affect the households of a community, and therefore offer starting points for individual vulnerability reduction (cf. Hufschmidt, 2011). The experts were asked to make assessments of all 31 indicators presented in Tables 1-3, except for "gender" (see Sect. 4.2.1). In the first part of the survey, the experts were asked to make assessments of the (1) importance of the household level indicators for identifying population groups vulnerable to (a) heat waves, (b) floods, (c) storms, and (d) natural hazards in general (including not only heat waves, floods and storms but also landslides, earthquakes etc., referred to as "generic vulnerability". In the second part of the survey, the experts were asked to assess the importance of the suggested community level (i.e. governance) indicators as starting points for vulnerability reduction regarding the above mentioned hazards (a-d). Also, the experts were asked to rate their (2) certainty regarding each assessment. For each indicator, they had the option to leave a comment. The experts were not provided with the complete information from Tables 1 to 3 in order to get the experts' opinion based on their own research and experience, not an assessment of the quality of the studies researched. The experts were given an assumption concerning the indicators' relation to vulnerability, and a short explanation of an indicators meaning if considered necessary ${ }^{4}$. Assessments were made via drop-down menus, i.e. for assessing importance: very important, important, rather important, rather not important, not important, not at all important; for assessing certainty: very certain, certain, rather certain, rather not certain, not certain, not at all certain.

\section{Results}

\subsection{Assessments of importance}

Table 4 shows the quantitative results of the survey. The assessment of importance differed across the individual categories (generic, heat, storm, flood). Seven of the eight traditional indicators were on average evaluated as "important": "medical problems", "residence type", "age", "household income", "ethnic minority", "disability" and "social isolation". Standard deviations are small particularly for "medical problems", the indicator that was rated most important as a generic indicator; this indicates a high consensus among the experts; also, the experts were certain regarding their assessment. "Age" as an indicator of vulnerability to heat waves was assessed with the highest average importance rating, highest certainty, and highest consent among the experts.

Four of the eight psychological indicators were on average evaluated as "important" regarding their generic importance: "trust in official information sources", "existence of role models", "perceived personal risk", and "perceived relative cost". All other psychological indicators were rated as "rather important" regarding their generic importance. Interestingly, "hazard experience" was only assessed as being "rather important" regarding its generic importance. However, in the individual categories, the indicator was considered to be "important". This emphasizes the importance of hazard-specific assessments of social vulnerability. The indicators "trust in official information sources" and "existence of role models" were evaluated as the most important of the psychological indicators. The standard deviations were relatively small, indicating high consensus among the experts, and the experts were certain regarding their assessments of these indicators.

Nine of the fourteen community level indicators were evaluated as "very important" or "important" for the category "generic". The indicators with the highest ratings refer to standards and plans: "existence and quality of building

\footnotetext{
${ }^{4}$ Examples for the presentation of indicators: for the household level indicators: (a) social isolation - assumption: people who are socially isolated (i.e. with few contacts outside their household) are more vulnerable to natural hazards. (b) Perceived protection responsibility - explanation: measures people's belief about who is responsible for conducting hazard protection measures (households or government). Assumption: people with high perceived protection responsibility for households are less vulnerable.
} 
codes", "existence of emergency plans", and "quality of urban/rural development plans". The importance of these indicators is also highlighted by the high consensus among the experts (e.g. nine out of ten experts assessed building codes as "very important" or "important"). The indicator "participatory decision-making" (PDM) was rated as "important" for the generic and the heat category, and as "very important" for the categories flood and storm, with the experts being certain regarding their assessment and low standard deviations for flood and storm. Standard deviation for heat was high, reflecting that some experts found PDM to be also very important regarding heat waves. "Availability and accessibility of hazard-related information" and "awareness-raising programs" were assessed as only being "rather important". We found this surprising since these aspects are often mentioned as key aspects in vulnerability reduction (e.g. Hahn et al., 2003; Marlin et al., 2007).

\subsection{Challenges regarding the use of indicators}

In the following, we will discuss challenges regarding the use of indicators, based on the experts' comments and complemented by research work regarding those comments.

\subsubsection{Household level indicators}

Many indicators used to assess vulnerability are ambiguous (also see below for a discussion of the indicator "gender"). One example is the indicator "age": old people are generally physically more vulnerable, but might be more likely to hold insurances against financial losses from natural hazards (Fekete, 2009; also see Steinführer and Kuhlicke, 2007). "Hazard experience" is assumed to reduce vulnerability, but some people with hazard experience might be more vulnerable due to a (false) sense of security or a reduction of perceived risk, based on prior low-impact hazard experiences or false warnings (cf. Shultz et al., 2005; Peacock et al., 2005). However, other studies find no negative influence of unnecessary evacuations on future evacuation behaviour (e.g. Baker 1991; Dow and Cutter, 1998). Sharma and Patt (2012) emphasize the importance of defining "hazard experience" in their attempt to "resolve the conflicting findings in literature about the effect of past hazard experience" (ibid., p. 409).

Some experts hold that the indicator "gender" should be included. There are indeed many studies that show higher vulnerability of women to natural hazards, especially in developing countries (Aguilar, 2010; Mearns and Norton, 2010), but also in industrialized countries, mainly due to a lack of financial resources (Masozera et al., 2007; Morrow and Enarson, 1996). Generally, it can be assumed that in societies where "women and girls have less access to and control over resources" (Demetriades and Esplen, 2010, p. 133), women are disproportionately affected by natural disasters. There is research finding men to be less likely to evacuate due to a belief they can effectively protect their homes, which potentially puts them in danger (Riad et al., 1999), although this may also be true for women being responsible for the home and children, especially in developing countries (Oswald Spring, 2008). Also, there is a high relation of female gender with fragility, which might be due to the higher percentage of females reaching old age (Fekete, 2010). Additionally, females show a higher risk perception and preparedness for taking action (Flynn et al., 1994; Fothergill, 1996). All over, we find "gender" to be a very ambiguous indicator, especially regarding industrialized countries (cf. AroraJonsson, 2011), and did therefore not include it in the expert survey.

Many studies use the indicator "single household" as an indicator for social isolation. However, it seems more important to what extent an individual is integrated into a social network outside the household (e.g. friends, neighbours, family) as such a network potentially provides crucial information and support in case of a disaster (Klinenberg, 2003).

A distinction between slow onset and sudden onset disasters might be more meaningful than distinguishing natural hazards in climatic terms. The underlying reasoning is the fact that with long warnings, e.g. for a snow-melt flood, issues that are crucial in a situation requiring a fast evacuation (such as physical strength, mobility) become less important.

The indicator "household income" is assumed to be a summary marker for a constellation of factors that measure disadvantages and resources for coping (cf. Fothergill and Peek, 2004). However, well-off households can still be vulnerable; it has been shown that the availability of means for carrying out hazard prevention measures does not automatically lead to their actual implementation (cf. Grothmann and Patt, 2005).

To find meaningful indicators is always a challenge, but particularly so with regard to psychological factors. For example, "perceived personal risk" can be measured in many different ways, probably touching different aspects of risk perception. Also, risk perception in itself is a complex issue, influenced by psychological, social and cultural components (cf. Wachinger and Renn, 2010; from Slovic, 1992). Using just one indicator for "personal risk perception" would imply an oversimplification of the matter - a sacrifice regularly made in indicator-based approaches.

The US and Europe have very different profiles for correlations of vulnerability, with some indicators such as social isolation, class, or household income (cf. Kovats and Hajat, 2008). Given that the majority of studies on vulnerability in industrialized countries relate to the US, the question of transferability of US study results to European and other industrialized countries requires further research (cf. Kuhlicke et al., 2011a).

\subsubsection{Governance indicators}

It is a challenge to define a set of governance indicators. Governance indicators are highly context specific and thus 
usually broadly described rather than precisely defined. Often, governance indicators lack a reasonable unit of measurement, which makes it difficult to use them for comparative vulnerability assessment. While it is difficult to assess the exact effects of, for instance, building codes and emergency plans on vulnerability, these indicators allow devising vulnerability reduction measures (e.g. improving the enforcement of building codes in flood-prone areas).

While there is general agreement about the relevance of "participatory decision-making" as an important indicator for identifying starting points for vulnerability reduction, the experts stressed the challenge of carrying out successful participatory decision-making leading to vulnerability reduction. In the experts' experience, disaster preparedness levels were often still unsatisfactory despite several participatory decision-making mechanisms. A seeming lack of success of such participation can obviously have many reasons; one might be the quality of the process itself (cf. Renn and Schweizer, 2009). Similarly, many local government programs that aim at raising people's awareness of natural hazards do not necessarily imply higher preparedness levels within a community. Vulnerability is a highly contextspecific phenomenon (cf. Füssel, 2007) and therefore calls for high-quality programs that are tailored to local conditions (cf. Kuhlicke et al., 2011b; also see Matthies and Krömker, 2000).

\section{Discussion}

The response rate to the survey was rather low (see Sect. 3), which poses a potential source of bias (cf. Kelley et al., 2003). A higher response rate might have led to different values for some of the indicators. Still, we assume that it would not have changed the overall picture of the importance ratings and therefore consider the response rate as acceptable. Also, there are no identifiable fundamental differences between respondents and non-respondents - they all have similar qualifications and research backgrounds. Reasons for non-participation were not given except by two experts, who stated they did not consider themselves the right experts for the survey.

In addition to the assessment of the indicators' importance, we were interested in potential dissent and consensus among the experts. To analyse this, we chose to perform a variance analysis, which is a controversial procedure for analysing rating-scale data. However, it has been shown that performing statistical analyses requiring interval-level data (such as variance analysis) on rating-scale data does not lead to substantial distortion in the results (Labovitz, 1970). Providing a high number of response categories can support the perception of the required equidistance between the categories, five to seven categories being assumed a sufficient number (Mayer, 2006, p. 82). Fewer answer categories might have led to higher standard deviations (SDs), which were rather low (SDs from 0.4 to 1.6, with an average of 0.95). Another critical issue is posed by the verbal representation of the answer categories, which are assumed to be less suitable for expressing equidistance between the categories than numerical representation (i.e. only assigning the extreme values "very important" and "not important at all" on a scale of one to six) (cf. Schulz and Renn, 2009). Our choice of verbal representation was led by its assumed higher convenience for the drop-down menu in the online survey tool we used (Survey Monkey). However, for future work, we would probably opt for numerical representation to avoid any confusion regarding the wording and better allow for the performance of statistical analyses.

In the survey, both the traditional and the psychological indicators were presented as indicators for identifying vulnerable population groups. That was because we were interested in the experts' assessments regarding the relevance of the psychological indicators as indicators complementary to the traditional ones. However, our reason for including psychological indicators is their importance with regard to loss prevention behaviour. An alignment of the survey question (i.e. as how important do the experts consider the psychological indicators for loss prevention behaviour) might have led to different results regarding the importance rating. Also, comparing the assessment of importance and certainty, one can see the tendency that the experts' certainty regarding their judgments increases with increasing importance ratings. With more research on the relevance of psychological factors, the certainty of experts and their assessments regarding these factors might also increase.

\section{Conclusions - a concept for integrating psychological and governance factors}

The results from the expert survey suggest that psychological indicators can be seen as complementary but not equal to the traditional indicators when it comes to vulnerability assessment; most of the psychological factors were assessed as being less important than the traditional factors for identifying vulnerable population groups. However, an expert survey with other experts might have led to different results. In an expert survey carried out by Müller et al. (2011) with practitioners (persons from the regional government, non-governmental organisations, communal planning institutions), psychological indicators such as "experience with floods", "knowledge about floods" and "knowledge about flood protection measures" were rated as being more important for urban vulnerability assessments than traditional indicators such as "age", "occupation status" and "gender" (ibid., p. 2116). In any case, when looking at how to refine vulnerability assessments, reduce vulnerability and build social capacity, we believe that surveys including psychological indicators - especially in combination with governance indicators - could offer extremely valuable insights for 
decision makers at the local level. There are three main reasons for this assumption: firstly, the literature review shows that there are many surveys and case studies finding a significant correlation between psychological factors and the likelihood of people to take private vulnerability reduction measures. Secondly, many of the psychological factors are potentially changeable in the short to medium term. Thirdly, unlike some traditionally recognized vulnerability factors (such as age or poverty), they can potentially be influenced by (local) decision makers or through (local) governance strategies (e.g. modes of risk communication, incentives for private vulnerability reduction measures, participatory processes). Being able to determine which governance factors can increase the likelihood of people adopting loss prevention behaviour would make psychological and governance factors a powerful couple. For example, participatory processes have been shown to change people's perception of natural hazards, their level of trust in authorities and their willingness to "initiate protective action" (Wachinger et al., 2012, p. 13). Programs and campaigns for disaster risk reduction based on insights regarding psychological factors and people's motivation to take private loss prevention measures can have a huge potential for overall loss prevention. Considering this, the costs of surveys that allow gaining these insights for a particular locality seem marginal. Governance has been recognized as playing a major role in reducing the vulnerability of individuals and communities. This is shown by our literature review and confirmed by the expert survey. However, despite insights into how, for example, participatory processes should be set up (e.g. Matthies and Krömker, 2000), according to the expert survey, apparently many of such processes in disaster risk reduction miss their objective of increasing preparedness. Including both psychological and governance aspects might improve the extent to which such processes are tailored to the needs of the people affected and thereby increase the effectiveness of the processes.

Following the aforementioned thoughts, we propose a pragmatic concept (see Fig. 1) to make efficient use of the different indicators and research instruments for assessments of social vulnerability and building of social capacity (cf. Tapsell et al., 2005).

Firstly, indicators of exposure to climatic and natural hazards (e.g. altitude above sea/river level) could be assessed. Secondly, for those regions which have turned out to show medium to high exposure, traditional indicators such as age, medical problems and household income could be gathered. Thirdly, psychological indicators such as trust in official information sources, existence of role models or risk perception could be evaluated (with a focus on regions that have been identified as vulnerable through the collection of traditional indicators). The collection of the psychological indicators will require setting up surveys. By applying surveys only to those regions that have been identified as vulnerable through the first two steps, the costs of such surveys would be reduced. Fourth, governance indicators could be

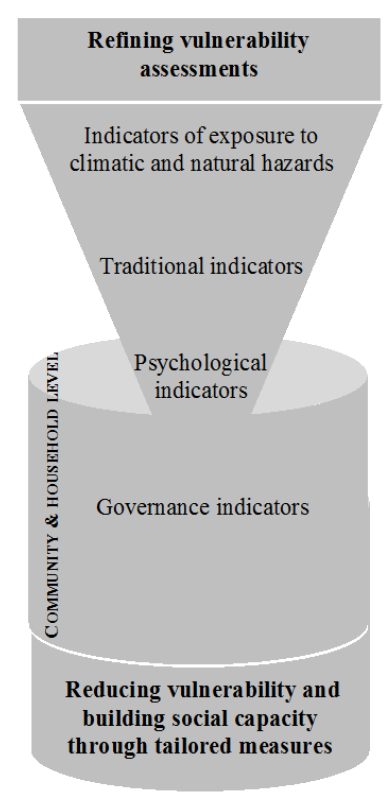

Fig. 1. Concept for integrating psychological and governance factors.

assessed to assist the planning of governance measures to reduce vulnerability. Based on the data gathered in the previous steps, these measures could be planned efficiently and targetgroup specific. Through this, the concept as described might support local decision makers, organisations and institutions in assessing vulnerability at community and household level and be useful for planning measures for social capacity building (cf. O'Sullivan, 2012). Nevertheless, to further improve such efforts, more research is necessary regarding the influence of psychological factors on the likelihood of people to take private vulnerability reduction measures.

The approach as presented is especially relevant against the background of an increasing "privatisation of risk" (Steinführer et al., 2009), that is, according to Kuhlicke et al. (2011a), promoted by changes in governance practices in many European countries with regard to natural hazards. People at risk are "encouraged or even required to take more responsibility for their actions" (ibid., p. 806). This often conflicts with people's perception that they have few chances to prevent losses from natural hazards (cf. Grothmann and Patt, 2005; Plapp and Werner, 2006). Consequently, it seems useful that people should become more aware of possible threats and means of protecting themselves. This emphasizes the importance of understanding the determinants of private loss prevention behaviour, but the "privatisation of risk" can be problematic when it leads to the "expectation that city residents $[\ldots]$ will be active consumers of public goods, $[\ldots]$ rather than "citizens" entitled to social protection" (Klinenberg, 2003, p. 232) - a perspective potentially leading to too high a burden on the citizens (cf. Steinführer, 2009). Claiming that people need to take responsibility to 
protect themselves from natural hazards should not absolve the state from its duty to protect its citizens and to tackle social inequality as a root cause of vulnerability.

Acknowledgements. We thank Katharina Beyerl and Harald Mieg from Humboldt University Berlin and two anonymous reviewers for useful comments and suggestions. All remaining errors are the fault of the three authors.

Edited by: C. Kuhlicke

Reviewed by: two anonymous referees

\section{References}

Adeola, F.: Flood Hazard Vulnerability: A Study of Tropical Storm Allison (TSA) Flood Impacts and Adaptation Modes in Louisiana, Quick Response Research Report 162, available at: http://www.colorado.edu/IBS/hazards/research/qr/qr162/ qr162.pdf (last access: 3 October 2011), 2003.

Adeola, F.: Katrina Cataclysm: Does Duration of Residency and Prior Experience Affect Impacts, Evacuation, and Adaptation Behavior Among Survivors?, Environ. Behav., 41, 459-489, doi:10.1177/0013916508316651, 2009.

Adger, N.: Vulnerability, Global Environ. Chang., 16, 268-281, doi:10.1016/j.gloenvcha.2006.02.006, 2006.

Adger, W., Brooks, N., Kelly, M., Bentham, M. A., and Eriksen, S.: New indicators of vulnerability and adaptive capacity, Report 7, Tyndall Centre for Climate Research, 2004.

Aguilar, L.: Climate Change and Disaster Mitigation. Gender Makes the Difference, International Union for Conservation of Nature, available at: http://www.icimod.org/?opg=949\&q=drr document\&document=999 (last access: 30 April 2013), 2010.

Aldrich, N. and Benson, W. F.: Disaster Preparedness and the Chronic Disease Needs of Vulnerable Older Adults, Preventing Chronic Disease, 5, 1-7, 2008.

Anderson-Berry, L. J.: Community Vulnerability to Tropical Cyclones: Cairns, 1996-2000, Nat. Hazards, 30, 209-232, 2003.

Araujo, A., Quesada-Aguilar, A., Aguilar, L., and Pearl, R.: Gender Equality and Adaptation, Women's Environment and Development Organization/World Conservation Union, 2008.

Arora-Jonsson, A.: Virtue and vulnerability: Discourses on women, gender and climate change, Global Environ. Chang., 21, 744751, doi:10.1016/j.gloenvcha.2011.01.005, 2011.

Baker, E. J.: Hurricane Evacuation Behavior, Int. J. Mass Emerg. Disast., 9, 287-310, 1991.

Barroca, B., Bernardara, P., Mouchel, J. M., and Hubert, G.: Indicators for identification of urban flooding vulnerability, Nat. Hazards Earth Syst. Sci., 6, 553-561, doi:10.5194/nhess-6-5532006, 2006.

Baumann, D. D. and Sims, J. H.: Flood insurance: Some determinants of adoption, Econ. Geogr., 54, 189-196, 1978.

Baxter, P. J.: The east coast Big Flood, 31 January-1 February 1953: a summary of the human disaster, Phil. Trans. R. Soc. Lond. A, 363, 1293-1312, doi:10.1098/rsta.2005.1569, 2005.

Birkmann, J.: Risk and vulnerability indicators at different scales: Applicability, usefulness and policy implications, Environ. Hazards, 7, 20-13, doi:10.1016/j.envhaz.2007.04.002, 2007.
Bollin, C., Cardenas, C., Hahn, H., and Krishna, S. V.: Disaster Risk Management by Communities and Local Governments, Regional Policy Dialogue (Natural Disasters Network), New York: InterAmerican Development Bank, 2003.

Botzen, W. J. W., Aerts, J. C. J. H., and van den Bergh, J. C. J. M.: Willingness of homeowners to mitigate climate risk through insurance, Ecol. Econ., 68, 2265-2277, doi:10.1016/j.ecolecon.2009.02.019, 2009.

Bradford, R. A., O'Sullivan, J. J., van der Craats, I. M., Krywkow, J., Rotko, P., Aaltonen, J., Bonaiuto, M., De Dominicis, S., Waylen, K., and Schelfaut, K.: Risk perception - issues for flood management in Europe, Nat. Hazards Earth Syst. Sci., 12, 2299-2309, doi:10.5194/nhess-12-2299-2012, 2012.

Brooks, N., Adger, W. N., and Kelly, P. M.: The determinants of vulnerability and adaptive capacity at the national level and the implications for adaptation, Global Environ. Chang., 15, 151163, doi:10.1016/j.gloenvcha.2004.12.006, 2005.

Carreño, M. L., Cardona, E., Darío, O., and Barbat, A. H.: A disaster risk management performance index, Nat. Hazards, 41, 1-20, doi:10.1007/s11069-006-9008-y, 2007.

Chavis, D. M. and Wandersman, A.: Sense of Community in the Urban Environment: A Catalyst for Participation and Community Development, Am. J. Commun. Psychol., 18, 55-81, doi:10.1007/BF00922689, 1990.

Cobb, C. W. and Rixford, C.: Lessons Learned from the History of Social Indicators, Redefining Progress, San Francisco, 1998.

Cordasco, K. M., Eisenman, D. P., Glik, D. C., Golden, J. F., and Asch, S. M.: "They Blew the Levee": Distrust of Authorities Among Hurricane Katrina Evacuees, J. Health Care Poor U., 18, 277-282, 2007.

Curtis, A., Mills, J. W., and Leitner, M.: Katrina and Vulnerability: The Geography of Stress, J. Health Care Poor U., 18, 315-330, doi:10.1353/hpu.2007.0029, 2007.

Cutter, S. L. and Finch, C.: Temporal and spatial changes in social vulnerability to natural hazards, Proc. Natl. Aca. Sci., 105, 23012306, doi:10.1073/pnas.0710375105, 2008.

Cutter, S. L., Boruff, B. J., and Shirley, W. L.: Social Vulnerability to Environmental Hazards, Soc. Sci. Quart., 84, 242-261, 2003.

Cutter, S. L., Burton, C. G., and Emrich, C. T.: Disaster Resilience Indicators for Benchmarking Baseline Conditions, J. Homel. Secur. Emerg., 7, Article 51, 1-22, 2010.

Demetriades, J. and Esplen, E.: The Gender Dimensions of Poverty and Climate Change Adaptation, in: Social Dimensions of Climate Change, edited by: Mearns, R. and Norton, A., The World Bank, 133-143, 2010.

Dow, K. and Cutter, S. L.: Crying Wolf: Repeat Responses to Hurricane Evacuation Orders, Coast. Manage., 26, 23-252, 1998.

Dwyer, A., Zoppou, C., Nielsen, O., Day, S., and Roberts, S.: Quantifying Social Vulnerability: A methodology for identifying those at risk to natural hazards, Geoscience Australia Record, 14, 101 pp., 2004.

Egli, T.: Hochwasservorsorge - Maßnahmen und ihre Wirksamkeit, Internationale Komission zum Schutz des Rheins, available at: http://www.iksr.org/fileadmin/user_upload/Dokumente_ de/RZ_iksr_dt.pdf (2 September 2011), 2002.

Faupel, C. E., Kelley, S. P., and Petee, T.: The impact of disaster education on household preparedness for Hurricane Hugo, Int. J. Mass Emerg. Disast., 10, 5-24, 1992. 
Fekete, A.: Validation of a social vulnerability index in context to river-floods in Germany, Nat. Hazards Earth Syst. Sci., 9, 393403, doi:10.5194/nhess-9-393-2009, 2009.

Fekete, A.: Assessment of Social Vulnerability for River-Floods in Germany, Ph.D., United Nations University, Institute for Environment and Human Security, Bonn, 2010.

Fleischhauer, M., Greiving, S., Flex, F., Scheibel, M., Stickler, T., Sereinig, N., Koboltschnig, G., Malvati, P., Vitale, V., Grifoni, P., and Firus, K.: Improving the active involvement of stakeholders and the public in flood risk management - tools of an involvement strategy and case study results from Austria, Germany and Italy, Nat. Hazards Earth Syst. Sci., 12, 2785-2798, doi:10.5194/nhess-12-2785-2012, 2012.

Flynn, J., Slovic, P., and Mertz, C. K.: Gender, race, and perception of environmental health risk, Risk Anal., 14, 1101-1108, 1994.

Fothergill, A.: Gender, risk, and disaster, Int. J. Mass Emerg. Disast., 14, 33-56, 1996.

Fothergill, A. and Peek, L. A.: Poverty and disasters in the United States: A review of recent sociological findings, Nat. Hazards, 32, 89-110, 2004.

Fouillet, A., Rey, G., Wagner, V., Laaidi, K., Empereur-Bissonet, P., Le Tertre, A., Frayssinet, P., Bessemoulin, P., Laurent, F., De Crouy-Chanel, P., Jougla, E., and Hémon, D.: Has the impact of heat waves on mortality changed in France since the European heat wave of summer 2003? A study of the 2006 heat wave, Int. J. Epidemiology, 37, 309-317, 2008.

Füssel, H.-M.: Vulnerability: A generally applicable conceptual framework for climate change research, Global Environ. Chang., 17, 155-167, doi:10.1016/j.gloenvcha.2006.05.002, 2007.

Garcia, E. M.: Earthquake preparedness in California: A survey of Irvine residents, Urban Resour., 5, 15-19, 1989.

Gladwin, C. H., Gladwin, H., and Peacock, W. G.: Modeling Hurricane Evacuation Decisions with Ethnographic Methods, Int. J. Mass Emerg. Disast., 19, 117-143, 2001.

Gladwin, H. and Peacock, W.: Warning and evacuation: A night for hard houses, in: Hurricane Andrew - Ethnicity, gender, and the sociology of disasters, edited by: Peacock, W. G., Morrow, B. H., and Gladwin, H., Routledge, 52-74, 1997.

Greiving, S.: Multi-risk assessment of Europe's regions, in: Measuring vulnerability to natural hazards: towards disaster resilient societies, edited by: Birkmann, J., United Nations University, Bonn, 380-398, 2006.

Grothmann, T.: Klimawandel, Wetterextreme und private Schadensprävention - Enwicklung, Überprüfung und praktische Anwendbarkeit der Theorie privater proaktiver WetterextremVorsorge, Ph.D., Otto-von-Guericke-Universität, Magdeburg, 2005.

Grothmann, T. and Patt, A.: Adaptive capacity and human cognition: the process of individual adaptation to climate change, Global Environ. Chang., 15, 199-213, doi:10.1016/j.gloenvcha.2005.01.002, 2005.

Grothmann, T. and Reusswig, F.: People at risk of flooding: Why some residents take precautionary action while others do not, Nat. Hazards, 38, 101-120, doi:10.1007/s11069-005-8604-6, 2006.

Gupta, J., Termeer, K., Klostermann, J., Meijerink S., van den Brink, M., Jong, P., Bootebook, S., and Bergsma, E.: The Adaptive Capacity Wheel: a method to assess the inherent characteristics of institutions to enable the adaptive capacity of society, Env- iron. Sci. Policy, 13, 459-471, doi:10.1016/j.envsci.2010.05.006, 2010.

Hahn, H., Villagrán L., J. C., and Hidajat, R.: Comprehensive Risk Management by Communities and Local Governments, Component III: Indicators and Other Disaster Risk Management Instruments for Communities and Local Governments, Regional Policy Dialogue Natural Disasters Network, Inter-American Development Bank, Washington, 2003.

Hinkel, J.: "Indicators of vulnerability and adaptive capacity": Towards a clarification of the science-policy interface, Global Environ. Chang., 21, 198-208, doi:10.1016/j.gloenvcha.2010.08.002, 2011.

Howe, P. D.: Hurricane preparedness as anticipatory adaptation: A case study of community businesses, Global Environ. Chang., 21, 711-720, doi:10.1016/j.gloenvcha.2011.02.001, 2011.

Hufschmidt, G.: A comparative analysis of several vulnerability concepts, Nat. Hazards, 58, 621-643, doi:10.1007/s11069-0119823-7, 2011.

Ikeda, S., Sato, T., and Fukuzono, T.: Towards an integrated management framework for emerging disaster risks in Japan, Nat Hazards, 44, 267-280, doi:10.1007/s11069-007-9124-3, 2008.

Jonkman, S. N.: Loss of life estimation in flood risk assessment, Proefschrift, University of Technology, Delft, 2007.

Jonkman, S. N., Maaskant, B., Boyd, E., and Levitan, M. L.: Loss of Life Caused by the Flooding of New Orleans after Hurricane Katrina: Analysis of the Relationship between Flood Characteristics and Mortality, Risk Anal., 29, 676-698, doi:10.1111/j.15396924.2008.01190.x, 2009.

Kaiser, R., Rubin, C. H., Henderson, A. K., Wolfe, M. I., Kieszak, S., Parrot, C. L., and Adcock, M.: Heat-related death and mental illness during the 1999 Cincinnati heat wave, Am. J. Foren. Med. Path., 22, 303-307, 2001.

Kalkstein, A. J. and Sheridan, S. C.: The social impacts of the heathealth watch/warning system in Phoenix, Arizona: assessing the perceived risk and response of the public, Int. J. Biometeorol., 52, 43-55, doi:10.1007/s00484-006-0073-4, 2007.

Kaufmann, D. and Kraay, A.: Governance indicators: Whre are we - where should we be going? World Bank Res. Obs., 23, 1-30, doi:10.1093/wbro/lkm012, 2008.

Kelley, K., Clark, B., Brown, V., and Sitzia, J.: Good practice in the conduct and reporting of survey research, Int. J. Quality Health Care, 15, 261-266, doi:10.1093/intqhe/mzg031, 2003.

Klinenberg, E.: Dying Alone: The Social Production of Urban Isolation, Ethnography, 2, 501-531, doi:10.1177/14661380122231019, 2001.

Klinenberg, E.: Heat wave: a social autopsy of disaster in Chicago, The University of Chicago Press, Chicago and London, 2003.

Knowlton, K., Rotkin-Ellman, M., King, G., Margolis, H. G., Smith, D., Solomon, G., Trent, R., and English, P.: The 2006 California Heat Wave: Impacts on Hospitalizations and Emergency Department Visits, Environ. Health Perspect., 117, 61-67, 2009.

Kovats, R. S. and Hajat, S.: Heat stress and public health: a critical review, Annu. Rev. Public Health, 29, 41-55, doi:10.1146/annurev.publhealth.29.020907.090843, 2008.

Kreibich, H. and Thieken, A. H.: Coping with floods in the city of Dresden, Germany, Nat. Hazards 51, 423-436, doi:10.1007/s11069-007-9200-8, 2009.

Kreibich, H., Thieken, A. H., Petrow, Th., Müller, M., and Merz, B.: Flood loss reduction of private households due to building 
precautionary measures - lessons learned from the Elbe flood in August 2002, Nat. Hazards Earth Syst. Sci., 5, 117-126, doi:10.5194/nhess-5-117-2005, 2005.

Kreibich, H., Christenberger, S., and Schwarze, R.: Economic motivation of households to undertake private precautionary measures against floods, Nat. Hazards Earth Syst. Sci., 11, 309-321, doi:10.5194/nhess-11-309-2011, 2011.

Krömker, D. and Mosler, H.: Human Vulnerability - Factors Influencing the Implementation of Prevention and Protection Measures: An Agent Based Approach, in: Global Environmental Change in Alpine Regions, Impact, Recognition, Adaptation, and Mitigation, edited by: Steininger, K. and Weck-Hannemann, H., Cheltenham, Edward Elgar, 93-112, 2002.

Kuhlicke, C., Steinführer, A., Begg, C., Bianchizza, C., Bründl, M., Buchecker, M., De Marchi, B., Die Masso Tarditti, M., Höppner, C., Komac, B., Lemkow, L., Luther, J., McCarthy, S., Pellizzoni, L., Renn, O., Scolobig, A., Supramaniam, M., Tapsell, S., Wachinger, G., Walker, G., Whittle, R., Zorn, M., and Faulkner, H.: Perspectives on social capacity building for natural hazards: outlining an emerging field of research and practice in Europe, Environ. Sci. Policy, 14, 804-814, doi:10.1016/j.envsci.2011.05.001, 2011a.

Kuhlicke, C., Scolobig, A., Tapsell, S., Steinführer, A., and De Marchi, B.: Contextualizing social vulnerability: findings from case studies across Europe, Nat. Hazards, 58, 789-810, doi:10.1007/s11069-011-9751-6, 2011b.

Kunreuther, H.: Mitigating Disaster Losses through Insurance, J. Risk Uncertainty, 12, 171-187, 1996.

Labovitz, S.: The Assignment of Numbers to Rank Categories, ASR, 35, 515-525, 1970.

Lindell, M. K. and Hwang, S. N.: Households' Perceived Personal Risk and Responses in a Multihazard Environment, Risk Anal., 28, 539-556, doi:10.1111/j.1539-6924.2008.01032.x, 2008.

Marlin, A., Olsen, L, Bruce, D., Ollerhead, J., Singh, K., Heckmann, J., Walters, B., Meadus, D., and Hanson, A.: Examining community adaptive capacity to address climate change, sea level rise and salt marsh restoration in maritime Canada, Coastal Wetlands Inst., available at: http://www.mta.ca/research/rstp/ CCIAP_Project_A1106_Final_Report1.pdf (last access: 15 October 2011), 2007.

Masozera, M., Bailey, M., and Kerchner, C.: Distribution of impacts of natural disasters across income groups: a case study of New Orleans. Ecol. Econ., 63, 299-306, doi:10.1016/j.ecolecon.2006.06.013, 2007.

Matthies, E. and Krömker, D.: Participatory planning - A heuristic for adjusting interventions to the context, J. Environ. Psychol., 20, 65-74, doi:10.1006/jevp.1999.0149, 2000.

Mayer, H. O.: Interview und schriftliche Befragung, Oldenbourg Verlag, Muenchen, 2006.

Mearns, R. and Norton, A.: Equity and Vulnerability in a Warming World, in: Social Dimensions of Climate Change, edited by: Mearns, R. and Norton, A., The World Bank, 1-44, 2010.

Meehl, G. A., Stocker, T. F., Collins, W. D., Friedlingstein, P., Gaye, A. T., Gregory, J. M., Kitoh, A., Knutti, R., Murphy, J. M., Noda, A., Raper, S. C. B., Watterson, I. G., Weaver, A. J., and Zhao, Z.C.: Global Climate Projections, in: Climate Change 2007: The Physical Science Basis. Contribution of WG I to the 4th Ass. Rep. of the IPCC, edited by: Solomon, S., Qin, D., Manning, M., Chen, Z., Marquis, M., Averyt, M., Tignor, M., and Miller, H. L.,
Cambridge Univ. Press, UK and NY, 2007.

Mileti, D. S. and Darlington, J. D.: The role of searching in shaping reactions to earthquake risk information, Social Problems, 44, 89-103, 1997.

Morrow, B. H.: Identifying and mapping community vulnerability, Disasters, 23, 1-18, 1999.

Morrow, B. H.: Community Resilience: A Social Justice Perspective, Community and Regional Resilience Initiative, CARRI Research Report 4, 2008.

Morrow, B. H. and Enarson, E.: Hurricane Andrew through Women's Eyes: Issues and Recommendations, Int. J. Mass Eemerg. Disast., 14, 5-22, 1996.

Müller, A., Reiter, J., and Weiland, U.: Assessment of urban vulnerability towards floods using an indicator-based approach - a case study for Santiago de Chile, Nat. Hazards Earth Syst. Sci., 11, 21070-2123, doi:10.5194/nhess-11-2107-2011, 2011.

Mulilis, J. P. and Duval, T. S.: Negative Threat Appeals and Earthquake Preparedness: A Person Relative to Event (PrE) Model of Coping With Threat, J. Appl. Soc. Psychol., 25, 1319-1339, doi:10.1111/j.1559-1816.1995.tb02620.x, 1995.

Mulilis, J. P., Duval, T. S., and Rogers, R.: The Effect of a Swarm of Local Tornados on Tornado Preparedness: A Quasi-Comparable Cohort Investigation, J. Appl. Soc. Psychol., 33, 1716-172, doi:10.1111/j.1559-1816.2003.tb01971.x, 2003.

Murphy, B. L.: Locating social capital in resilient communitylevel emergency management, Nat. Hazards, 41, 297-315, doi:10.1007/s11069-006-9037-6, 2007.

Mustafa, D., Ahmed, S., Saroch, E., and Bell, H.: Pinning down vulnerability: from narratives to numbers, Disasters, 35, 62-86, doi:10.1111/j.0361-3666.2010.01193.x, 2011.

Norris, F. H., Stevens, S. P., Pfefferbaum, B., Wyche, K. F., and Pfefferbaum, R. L.: Community resilience as a metaphor, theory, set of capacities, and strategy for disaster readiness, Am. J. Community Psychol., 41, 127-150, doi:10.1007/s10464-007-9156-6, 2008.

O’Sullivan, J. J., Bradford, R. A., Bonaiuto, M., De Dominicis, S., Rotko, P., Aaltonen, J., Waylen, K., and Langan, S. J.: Enhancing flood resilience through improved risk communications, Nat. Hazards Earth Syst. Sci., 12, 2271-2282, doi:10.5194/nhess-122271-2012, 2012.

Oswald Spring, Ù.: Gender and Disasters -Human, Gender, and Environmental Security: A HUGE Challenge, SOURCE UNU-EHS, 8, available at: http: //www.munichrefoundation.org/dms/MRS/Documents/ Source2008_Oswald_SpringGenderAndDisasters.pdf (last access: 24 April 2013), 2008.

Peacock, W. G.: Hurricane mitigation status and factors influencing mitigation status among Florida's single-family homeowners, Nat. Hazards Rev., 4, 149-158, doi:10.1061/(ASCE)15276988(2003)4:3(149), 2003.

Peacock, W. G., Brody, S. D., and Highfield, W.: Hurricane risk perceptions among Florida's single family homeowners, Landscape Urban Plan., 73, 120-135, doi:10.1016/j.landurbplan.2004.11.004, 2005.

Pearce, L.: Disaster Management and Community Planning, and Public Participation: How to Achieve Sustainable Hazard Mitigation, Nat. Hazards, 28, 211-228, 2003.

Pearce, L.: The Value of Public Participation during a Hazard, Impact, Risk and Vulnerability (HIRV) Analysis, Mitigation Adap- 
tation Strat. Global Change, 10, 411-441, doi:10.1007/s11027005-0054-7, 2005.

Peguero, A. A.: Latino disaster vulnerability - The dissemination of hurricane mitigation information among Florida's homeowners, Hispanic J. Behavioral Sci., 28, 522, doi:10.1177/0739986305284012, 2006.

Plapp, T. and Werner, U.: Understanding risk perception from natural hazards: Examples from Germany, in: RISK21 - Coping with Risks due to Natural Hazards in the 21st century, edited by: Ammann, W., Dannenmann, S., and Vulliet, L., Taylor and Francis Group, London, 101-108, 2006.

Reid, C. E., O’Neill, M. S., Gronlund, C. J., Brines, S. J., Brown, D. G., Diez-Roux, A. V., and Schwartz, J.: Mapping community determinants of heat vulnerability, Environ. Health Perspect., 117, 1730-1736, doi:10.1289/ehp.0900683, 2009.

Renn, O. and Schweizer, P.-J.: Inclusive risk governance: concepts and application to environmental policy making, Environ. Policy Gov., 19, 174-185, doi:10.1002/eet.507, 2009.

Riad, J. K., Norris, F. H., and Ruback, R. B.: Predicting Evacuation in Two Major Disasters: Risk Perception, Social Influence, and Access to Resources, J. Appl. Psychol., 29, 918-934, doi:10.1111/j.1559-1816.1999.tb00132.x, 1999.

Rogers, R. W. and Prentice-Dunn, S.: Protection motivation theory, in: Handbook of health behaviour research, I: Personal and social determinants, edited by: Gochman, D. S., New York, NY, Plenum, 113-132, 1997.

Romero-Lankao, P., Qin, H., and Dickinson, K.: Urban vulnerability to temperature-related hazards: A meta-analysis and metaknowledge approach, Global Environ. Chang., 22, 670-683, doi:10.1016/j.gloenvcha.2012.04.002, 2012.

Ronan, K. R., Crelling, K., and Johnston, D.: Correlates of hazards education for youth: a replication study, Nat. Hazards, 53, 503526, doi:10.1007/s11069-009-9444-6, 2010.

Schulz, M. and Renn, O. (Eds.): Methodik des Delphis, in: Das Gruppendelphi, VS Verlag für Sozialwissenschaften, 2009.

Scolobig, A., De Marchi, B., and Borga, M.: The missing link between flood risk awareness and preparedness: findings from case studies in an Alpine Region, Nat. Hazards, 63, 499-520, doi:10.1007/s11069-012-0161-1, 2012.

Semenza, J. C., Rubin, C. H., Falter, K. H., Selanikio, J. D., Flanders, W. D., Howe, H. L., and Wilhelm, J. L.: Heat-related deaths during the July 1995 heat wave in Chicago, N. Engl. J. Med., 335, 84-90, doi:10.1056/NEJM199607113350203, 1996.

Sharma, U. and Patt, A.: Disaster warning response: the effects of different types of personal experience, Nat. Hazards, 60, 409423, doi:10.1007/s11069-011-0023-2, 2012.

Sheridan, S. C.: A survey of public perception and response to heat warnings across four North American cities: an evaluation of municipal effectiveness, Int. J. Biometeorol., 52, 3-15, doi:10.1007/s00484-006-0052-9, 2007.

Shultz, J. M., Russel, J., and Espinel, Z.: Epidemiology of tropical cyclones: the dynamics of disaster, disease and development, Epidemiol. Rev., 27, 21-35, doi:10.1093/epirev/mxi011, 2005.

Slovic, P.: Perception of Risk Reflections on the Psychometric Paradigm, in: Social Theories of Risk, edited by: Krimsky, S. and Golding, D., Praeger, Westport, 1992, 117-152, 1992.

Stanley, J.: Promoting Social Inclusion in Adaptation to Climate Change, Discussion Paper, Monash University/Sustainability Institute, Victoria, 2010.
Steinführer, A. and Kuhlicke, C.: Social vulnerability and the 2002 flood, Country Report Germany (Mulde River), Leipzig, 2007.

Steinführer, A, Kuhlicke, C., De Marchi, B., Scolobig, A., Tapsell, S., and Tunstall, S.: Local Communities at Risk from Flooding: Social Vulnerability, Resilience and Recommendations for Flood Risk Management in Europe, Leipzig, available at: http://www.ufz.de/export/data/1/26010_Task11_Broschuere_ 7_09.pdf (last access: 4 August 2012), 2009.

Tan, J.: Commentary: People's vulnerability to heat wave, Int. J. Epidemiol, 37, 318-320, 2008.

Tan, J., Zheng, Y., Song, G,. Kalkstein, L., Kalkstein, A., and Tang, X.: Heat wave impacts on mortality in Shanghai, 1998 and 2003, Int. J. Biometeorol., 51, 193-200, doi:10.1007/s00484006-0058-3, 2007.

Tapsell, S., Penning-Rowsell, E. C., Tunstall, S. M., and Wilson, T. L.: Vulnerability to flooding: health and social dimensions, Phil. Trans. R. Soc. Lond. A, 360, 1511-1525, doi:10.1098/rsta.2002.1013, 2002.

Tapsell, S., Tunstall, S., Green, C., and Fernández-Bilbao, A.: Task 11 Social Indicator Set, Floodsite Project Report, available at: http://www.floodsite.net/html/partner_area/project_docs/M11. 1_Indicator-set_7-05.pdf (last access: 2 March 2012), 2005.

Tapsell, S., Mc Carthy, S., Faulkner, H., and Alexander, M.: Social Vulnerability to Natural Hazards. CapHaz-Net Consortium, Middlesex University, United Kingdom, 2010.

Tunstall, S., Tapsell, S., Green, C., Floy, P., and George, C.: The health effects of flooding: social research results from England and Wales, J. Water Health, 4, 365-318, doi:10.2166/wh.2006.031, 2006.

Ueland, J. and Warf, B.: Racialized Topographies: Altitude and Race in Southern Cities, Geograph. Rev., 96, 50-78, doi:10.1111/j.1931-0846.2006.tb00387.x, 2006.

UNISDR: A Ten-point checklist for local governments Ten essentials for making cities resilient, available at: http://www.unisdr.org/english/campaigns/campaign2010-2011/ documents/230_tenpointchecklist.pdf (last access: 14 May 2011), 2010.

US Department of Commerce, National Weather Service's Office of Meteorology: A Summary of Natural Hazard Fatalities for 1994 in the United States, US Government Printing Office, Washington, 1995.

Wachinger, G. and Renn, O.: Risk Perception and Natural Hazards. CapHaz-Net WP3 Report, DIALOGIK NonProfit Institute for Communication and Cooperative Research, available at: http://caphaz-net.org/outcomes-results/ CapHaz-Net_WP3_Risk-Perception.pdf (last access: 4 November 2012), 2010.

Wachinger, G., Renn, O., Begg, C., and Kuhlicke, C.: The risk perception paradox: implications for governance and communication of natural hazards, Risk Anal., doi:10.1111/j.15396924.2012.01942.x, online first, 2012.

White, I. and Howe, J.: Policy and Practice - Flooding and the Role of Planning in England and Wales: A Critical Review, J. Environ. Plan. Manage., 45, 735-745, doi:10.1080/0964056022000013093, 2002.

Whitman, S., Good, G., Donoghue, E. R., Benbow, N., Shou, W., and Mou, S.: Mortality in Chicago Attributed to the July 1995 Heat Wave, Am. J. Public Health, 87, 1515-1518, 1997. 
Wisner, B., Blaikie, P., Cannon, T., and Davis, I.: At Risk, Natural hazards, people's vulnerability and disasters, 2nd Edn., Routledge, London and New York, 2004.

World Bank and United Nations: Natural hazards, unnatural disasters: the economics of effective prevention, The World Bank, Washington, 2010.
Yardley, J., Sigal, R. J., and Kenny, G. P.: Heat health planning: The importance of social and community factors, Global Environ. Chang., 21, 670-679, doi:10.1016/j.gloenvcha.2010.11.010, 2011.

Zoraster, R. M.: Vulnerable Populations: Hurricane Katrina as a Case Study, Prehospital Disaster Medicine, 25, 74-78, 2010. 